\title{
SISTEM PENDUKUNG KEPUTUSAN PEMILIHAN RUMAH SAKIT DENGAN PELAYANAN RAWAT INAP TERBAIK
}

\author{
Mustika Mentari ${ }^{1}$, Chintya Puspa Dewi ${ }^{2}$ \\ 1,2 Jurusan Teknologi Informasi, Program Studi Teknik Informatika, Politeknik Negeri Malang \\ ${ }^{1}$ must.mentari@ polinema.ac.id, ${ }^{2}$ chintyadewi437@ gmail.com
}

\begin{abstract}
Abstrak
Rumah sakit adalah tempat pelayanan kesehatan yang pasti sangat diperlukan oleh masyarakat. Pelayanan tersebut dilihat dari efisiensi, sarana dan prasarana yang memadai, dan faktor lainnya. Pelayanan kesehatan rumah sakit khususnya rawat inap menjadi permasalahan jika tidak dilakukan dengan baik. Hal tersebut berpengaruh tidak hanya pada kesehatan fisik, tetapi juga kesehatan mental pasien. Lebih parahnya pelayanan yang tidak baik,terhadap pasien dapat berakibat pada kematian. Efisiensi pelayanan rawat inap juga termasuk hal yang penting bagi pasien, khususnya yang harus dirawat di rumah sakit. Semakin cepat penanganan pasien rawat inap akan semakin baik. Pihak rumah sakit melakukan sensus harian untuk meninjau dan meningkatkan kualitas pelayanan rawat inap. Kriteria pelayanan rawat inap adalah Bed Occupancy Ratio, Bed Turn Over, Turn Over Interval, dan Average Length of Stay. Untuk membantu masyarakat dalam memilih rumah sakit berdasar pelayanan rawat inap terbaik dapat diatasi dengan sistem pendukung keputusan. Oleh karena itu penelitian ini bertujuan membuat sistem pendukung keputusan yang dilakukan dengan kriteria yang sudah dijelaskan dan juga menggunakan beberapa alternatif berupa rumah sakit yang ada di wilayah Kota Batu. Metode yang digunakan adalah gabungan SAW (Simple Additive Weighting) dan TOPSIS (Technique For Order Preference By Similarity To Ideal Solution). Metode ini dipilih karena menggunakan persamaan matematis yang lebih sederhana untuk mendapatkan solusi terbaik. Hasil pengujian dapat digunakan untuk membantu masyarakat dalam pemilihan rumah sakit
\end{abstract}

Kata kunci : Sistem Pendukung Keputusan, SAW, TOPSIS, pelayanan rumah sakit.

\section{Pendahuluan}

Rumah sakit adalah tempat pelayanan kesehatan yang pasti sangat diperlukan oleh masyarakat, khususnya fasilitas rawat inap yang disediakan. Pemilihan rumah sakit dengan pelayanan rawat inap terbaik berpengaruh terhadap kenyamanan pasien yang membutuhkan dukungan fisik ataupun mental. Pasien luka bakar hasil study penelitian (Palmu, 2015) mengalami gangguan mental tertentu setelah beberapa bulan dirawat. Artikel (Yousufuddin, 2018) menjelaskan pula bahwa terdapat beberapa penyakit seperti gagal jantung, anemia, dll yang memungkinkan pasien dapat mengalami rawat inap kembali (berulang). Terjadi pula realita kejadian sesuai sumber (Reza, 2020). Artikel tersebut menjelaskan peristiwa yang menimpa seorang nenek di Jepara yang meninggal di parkiran setelah menunggu 2 jam tidak mendapat brankar atau ranjang beroda rumah sakit. Hal ini terjadi karena fasilitas yang kurang dan pihak rumah sakit tidak melakukan evaluasi dari data statistik rumah sakit. Pelayanan rumah sakit yang tidak tanggap utamanya dalam rawat inap akan berpengaruh bahkan terhadap keselamatan hidup pasien

Berdasarkan permasalahan-permasalahan dan peristiwa yang telah dibahas dapat diketahui akan pentingnya sistem pendukung keputusan (SPK) pemilihan rumah sakit khususnya dengan fasilitas rawat inap Menurut artikel (Sudra, 2020) yang melakukan study menggunakan data statistika menunjukkan bahwa untuk membantu pemilihan rumah sakit dibutuhkan sistem pendukung keputusan yang akan menghasilkan solusi berdasarkan data dan mengurangi subyektifitas. Dengan begitu solusi atau keputusan yang dihasilkan lebih tepat. Selain itu, secara berkebalikan pada artikel (Ortiz-Barrios, 2020), identifikasi tingkat ketidak kesiapsiagaan rumah sakit yang rendah perlu dilakukan untuk mengetahui kesiapsiagaan terhadap bencana yang terjadi. Penelitian yang dilakukan oleh (Catho, 2020) membahas tentang penggunaan sistem pendukung keputusan menghasilkan beberapa hal diantaranya cara yang efektif untuk kecepatan pelayanan ataupun meningkatkan kepatuhan dokter terhadap pedoman perawatan pasien

Seiring dengan berkembangnya teknologi saat ini, banyak sistem pendukung keputusan yang diimplementasikan kedalam suatu aplikasi, baik itu berbasis web (paul, 2020), (Siddiqui, 2018) maupun berbasis mobile (termasuk android) (Ogunti, 2018), (Ismail, 2015). Dengan begitu, sistem yang telah dibuat dapat lebih memudahkan dan meningkatkan efisiensi dalam pengambilan keputusan karena semua perhitungan dilakukan oleh sistem. Karena kemampuan manusia dalam berpikir sangatlah 
terbatas. Dalam pengimplementasian sistem pendukung keputusan, diperlukan suatu metode untuk menyajikan informasi, mengolah data menggunakan perhitungan matematis, dan menentukan solusi yang tepat. Banyak metode SPK yang telah digunakan dalam penelitian sebagai solusi untuk mengambil keputusan dengan banyak kriteria. Namun pada penelitian ini, penulis menggunakan penggabungan metode SAW (Büyüközkan, 2019) dan TOPSIS (Konstantinos, 2019) untuk membantu memilih rumah sakit dengan pelayanan rawat inap terbaik di wilayah Kota Batu. Menurut Gregorius (2013), metode ini dinilai cukup efisien karena menggunakan persamaan matematis yang lebih sederhana.

Menurut Hatta (2013) ada indikator atau kriteria yang digunakan untuk menghitung statistik kesehatan, antara lain Bed Occupancy Ratio untuk menghitung persentase tempat tidur terisi, Bed Turn Over Interval untuk menghitung produktivitas tempat tidur, Turn Over Interval menghitung ratarata waktu luang tempat tidur, Average Length of Stay menghitung rata-rata lama pasien dirawat. Berdasarkan data akreditasi rumah sakit, di wilayah Batu hanya ada 2 rumah sakit dengan rating tertinggi yaitu RS Baptis dan RS Karsa Husada, sedangkan 3 lainnya belum mencapai rating tertinggi. Tujuan dari penelitian ini adalah menentukan alternatif terbaik dari sejumlah alternatif atau rumah sakit yang ada di wilayah Kota Batu berdasarkan kriteria pelayanan rawat inap rumah sakit.

\section{Landasan Teori}

\subsection{Sistem Pendukung Keputusan}

Menurut Permana (2015) Sistem pendukung keputusan adalah sebuah sistem yang dapat membantu seseorang dalam mengambil keputusan dari berbagai jenis pilihan, dilakukan dengan cara yang akurat dan sesuai dengan sasaran yang diinginkan. Sistem pendukung keputusan menyediakan informasi, pengolahan data, dan hasil dari pengambilan keputusan untuk membantu memberi solusi dari suatu masalah semi terstruktur dengan baik.

\subsection{Indikator Pelayanan Rawat Inap Rumah Sakit}

Terdapat empat jenis pelayanan rawat inap rumah sakit dalam (DepKes RI, 2005) yaitu, Bed Occupancy Ratio, Bed Turn Over Interval, Turn Over Interval, dan Average Length of Stay. Masingmasing penjelasan pelayanan-pelayanan tersebut adalah sebagai berikut :

\section{1) BOR (Bed Occupancy Ratio)}

BOR adalah prosentase pemakaian tempat tidur dalam satuan waktu tertentu. Prosentase ini diperoleh dari jumlah hari perawatan dengan jumlah tempat tidur. Hasilnya dapat memberikan gambaran tinggi atau rendahnya tingkat pemanfaatan tempat tidur di rumah sakit. Nilai BOR yang ideal adalah antara 60\%-86\% dalam satu tahun (DepKes RI, 2005).

\section{2) BTO (Bed Turn Over Interval)}

BTO adalah frekuensi pemakaian tempat tidur dalam satu periode atau berapa kali tempat tidur dipakai dalam satu satuan waktu tertentu. Hasilnya dapat digunakan untuk perkiraan waktu mengganti tempat tidur dan menjaga ketersediaannya. Satu tempat tidur idealnya dipakai 40-50 kali dalam satu tahun (DepKes RI, 2005).

\section{3) TOI (Turn Over Interval)}

TOI adalah rata - rata rentang waktu tempat tidur tidak ditempati dari waktu telah diisi ke saat terisi berikutnya dalam satu periode. Satuan dari rentang waktu ini adalah hari. Idealnya tempat tidur kosong antara $1-3$ hari (DepKes RI, 2005).

\section{4) AVLOS (Average Length of Stay)}

AVLOS adalah rata - rata lama rawat inap pasien dalam rumah sakit. Indikator ini akan memberikan gambaran tingkat efisiensi pelayanan rumah sakit. Rata - rata lama rawat inap pasien yang ideal adalah 6 - 9 hari (DepKes RI, 2005).

\subsection{SAW (Simple Additive Weight) dan TOPSIS (Technique for Order Preference by Similarity of Ideal Solution)}

Menurut Fishburn dan MacCrimmon dalam (Munthe, 2013) mengemukakan bahwa Metode Simple Additive Weight (SAW) yang sering juga dikenal dengan istilah metode penjumlahan terbobot mempunyai konsep dasar dengan mencari penjumlahan terbobot pada setiap alternatif untuk semua atribut. Metode SAW adalah salah satu contoh dari metode Multi-Attribute Decision Making (MADM) dan Weighted Sum Model (WSM) yang paling sederhana.

Artikel (Fristy, 2017) menjelaskan bahwa metode TOPSIS adalah salah satu metode pengambilan keputusan multikriteria yang pertama kali diperkenalkan oleh Yoon dan Hwang tahun 1981. TOPSIS didasarkan pada konsep, alternatif terpilih yang baik tidak hanya memiliki jarak terpendek dari solusi ideal positif, namun juga memiliki jarak terpanjang dari solusi ideal negatif. Metode TOPSIS memiliki konsep yang sederhana dan mudah dipahami. Perhitungan dapat dilakukan dengan efisien dan cepat. Namun metode ini kurang baik digunakan jika bobot yang didapat memperhitungkan hubungan antar kriteria. Metode 
TOPSIS bisa digabungkan dengan metode lainnya untuk menghasilkan keputusan yang tepat, contohnya Fuzzy dan TOPSIS, AHP dan TOPSIS, TOPSIS dan WP, serta metode - metode lainnya.

\section{Metodologi Penelitian}

\subsection{Studi Literatur}

Melakukan pengumpulan informasi dan konsep dari penelitian - penelitian yang telah dilakukan sebelumnya dengan topik yang hampir sama. Hasilnya akan dijadikan referensi dan kajian pendukung dalam penelitian yang dilakukan penulis.

\subsection{Pengumpulan Data}

Data alternatif, kriteria dan nilai setiap indikator pelayanan rumah sakit yang dikumpulkan bersumber dari data Indikator Kinerja Pelayanan Rumah Sakit Kota Batu Tahun 2018 di laman resmi pemerintah penyedia data yaitu https://data.go.id/.

Untuk data pendukung lainnya seperti pencarian bobot setiap kriteria, menggunakan kuesioner yang dibagikan kepada masyarakat untuk diisi. Kemudian hasilnya akan dianalisis. Analisis yang dilakukan dengan cara menghitung rata - rata hasil kuesioner setiap kriteria (total nilai respon dibagi total responden), kemudian menjumlahkan nilai rata-rata setiap kriteria. Setelah itu melakukan normalisasi untuk masing-masing kriteria (rata - rata setiap kriteria / total rata - rata).

\subsection{Penggabungan Metode SAW dan Metode TOPSIS}

Algoritma dalam penggabungan metode SAW dan metode TOPSIS ditunjukkan dalam diagram blok di bawah ini :

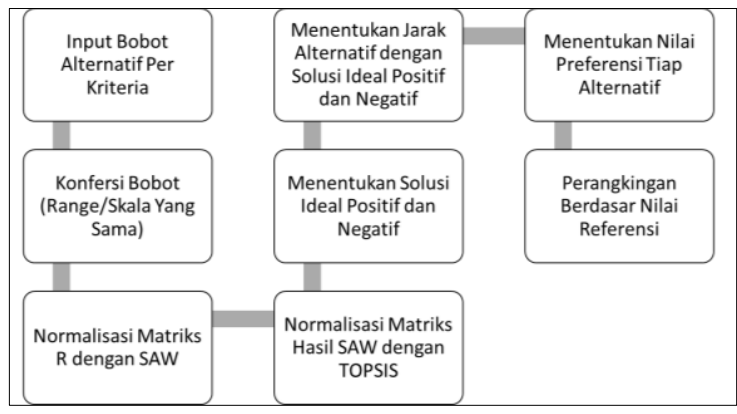

Gambar 1. Diagram Blok Penggabungan Metode SAW dan Metode TOPSIS

\section{Hasil dan Pembahasan}

\subsection{Hasil}

Hasil dari penelitian adalah implementasi penggabungan metode SAW dan metode TOPSIS untuk membantu pengambilan keputusan rumah sakit dengan pelayanan rawat inap terbaik di wilayah Kota Batu menggunakan kriteria - kriteria yang telah ditentukan. Seperti pada penelitian sebelumnya, metode SAW digunakan untuk mencari nilai matriks normalisasi R. Sedangkan metode TOPSIS digunakan untuk langkah selanjutnya, yaitu untuk menentukan alternatif terbaik dengan menghitung jarak positif dan negatifnya.

\subsection{Pembahasan}

Terdapat 4 kriteria untuk menentukan rumah sakit dengan pelayanan rawat inap terbaik dengan rincian sebagai berikut:

Tabel 1. Kriteria Perhitungan

\begin{tabular}{|l|c|c|}
\hline \multicolumn{1}{|c|}{ Kriteria } & Bobot (w) & Atribut \\
\hline $\begin{array}{l}\text { BOR (Bed Occupancy } \\
\text { Ratio) }\end{array}$ & 0.3 & Benefit \\
\hline BTO (Bed Turn Over) & 0.26 & Benefit \\
\hline TOI (Turn Over Interval) & 0.18 & Cost \\
\hline $\begin{array}{l}\text { AVLOS (Average } \\
\text { Length of Stay) }\end{array}$ & 0.27 & Cost \\
\hline
\end{tabular}

Terdapat 6 alternatif rumah sakit di wilayah Kota Batu yang akan digunakan oleh penulis. Rincian datanya adalah sebagai berikut:

Tabel 2. Data setiap alternatif sesuai kriteria

\begin{tabular}{|l|c|c|c|c|}
\hline \multirow{2}{*}{ Alternatif } & \multicolumn{4}{|c|}{ Kriteria } \\
\cline { 2 - 5 } & BOR & BTO & TOI & AVLOS \\
\hline $\begin{array}{l}\text { RS Karsa } \\
\text { Husada }\end{array}$ & 47.4 & 50.2 & 3.8 & 3.4 \\
\hline RS Baptis Batu & 44.4 & 56.2 & 3.6 & 2.6 \\
\hline $\begin{array}{l}\text { RS } \\
\text { Bhayangkara }\end{array}$ & 74.4 & 76.6 & 1.2 & 2.5 \\
\hline $\begin{array}{l}\text { RS dr. Etty } \\
\text { Asharto }\end{array}$ & 35 & 50.9 & 4.7 & 2.6 \\
\hline RSIA HAJI & 33.5 & 62.1 & 3.9 & 2.1 \\
\hline RS PUNTEN & 36.5 & 33.4 & 7 & 3.5 \\
\hline
\end{tabular}

Berikut langkah - langkah dalam pengambilan keputusan:

\section{Metode SAW}

Langkah 1: Mengkonversi nilai matriks keputusan X pada Tabel 2. menjadi nilai dengan skala yang sama.

1: Sangat Buruk

2: Buruk

3: Cukup

4: Baik

5: Sangat Baik 
Tabel 3. Konversi matriks keputusan

\begin{tabular}{|c|c|c|}
\hline Kriteria & Range Nilai & Nilai Konversi \\
\hline \multirow{4}{*}{ BOR } & $>0-<=20$ & 1 \\
\cline { 2 - 3 } & $>20-<=40$ & 2 \\
\cline { 2 - 3 } & $>40-<=60$ & 3 \\
\cline { 2 - 3 } & $>60-<=80$ & 4 \\
\cline { 2 - 3 } & $>80-<=100$ & 5 \\
\hline \multirow{4}{*}{ BTO } & $>0-<=15$ & 1 \\
\cline { 2 - 3 } & $>15-<=30$ & 2 \\
\cline { 2 - 3 } & $>30-<=45$ & 3 \\
\cline { 2 - 3 } & $>45-<=60$ & 4 \\
\cline { 2 - 3 } TOI & $>60-<=75$ & 5 \\
\hline & $>0-<=3$ & 5 \\
\cline { 2 - 3 } & $>3-<=6$ & 4 \\
\cline { 2 - 3 } & $>6-<=9$ & 3 \\
\cline { 2 - 3 } & $>9-<=12$ & 2 \\
\cline { 2 - 3 } & $>12-<=15$ & 1 \\
\hline \multirow{5}{*}{ AVLOS } & $>0-<=3$ & 5 \\
\cline { 2 - 3 } & $>3-<=6$ & 4 \\
\cline { 2 - 3 } & $>6-<=9$ & 3 \\
\cline { 2 - 3 } & $>9-<=12$ & 2 \\
\cline { 2 - 3 } & $>12-<=15$ & 15 \\
\hline
\end{tabular}

Persamaan untuk matriks keputusan X, adalah:

$$
\mathrm{X}=\left[\begin{array}{cccc}
x_{11} & x_{12} & \ldots & x_{1 n} \\
x_{21} & x_{22} & \ldots & x_{2 n} \\
\vdots & \vdots & & \vdots \\
x_{m 1} & x_{m 2} & \ldots & x_{m n}
\end{array}\right]
$$

Berdasarkan range nilai konversi dan persamaan (1), maka didapatkan hasil matriks keputusan $\mathrm{X}$ seperti berikut:

$$
X=\left[\begin{array}{llll}
3 & 4 & 4 & 4 \\
3 & 4 & 4 & 5 \\
4 & 5 & 5 & 5 \\
2 & 4 & 4 & 5 \\
2 & 5 & 4 & 5 \\
2 & 3 & 3 & 4
\end{array}\right]
$$

Langkah 2: Membuat normalisasi matriks R, dengan persamaan (2) berikut:

$$
\begin{aligned}
& r_{i j}= \begin{cases}\frac{x_{i j}}{\operatorname{Max} x_{i j}} & \text { jika } \mathrm{j} \text { adalah atribut bene } \mathrm{fit} \\
\frac{\operatorname{Min} x_{i j}}{x_{i j}} & \text { jika } \mathrm{j} \text { adalah atribut cost }\end{cases} \\
& r_{11}=\frac{3}{\max \{3: 3: 4: 2: 2: 2)}=\frac{3}{4}=0.75 \\
& r_{12}=\frac{4}{\max \{4: 4: 5: 4: 5: 3)}=\frac{4}{5}=0.8
\end{aligned}
$$

dan seterusnya ..., hingga diperoleh matriks normalisasi R:

$$
\mathrm{R}=\left[\begin{array}{cccc}
0.75 & 0.8 & 0.75 & 1 \\
0.75 & 0.8 & 0.75 & 0.8 \\
1 & 1 & 0.6 & 0.8 \\
0.5 & 0.8 & 0.75 & 0.8 \\
0.5 & 1 & 0.75 & 0.8 \\
0.5 & 0.6 & 1 & 1
\end{array}\right]
$$

Setelah memperoleh matriks normalisasi $\mathrm{R}$ menggunakan metode SAW, kemudian dilanjutkan dengan mencari nilai matriks ternormalisasi terbobot (Y) menggunakan metode TOPSIS.

\section{Metode TOPSIS}

Langkah 1: Menentukan matriks skor normalisasi terbobot (Y) dengan persamaan (3):

$$
y_{i j}=w_{j} \times r_{i j}
$$

Contoh perhitungan untuk mencari nilai $\mathrm{y}_{\mathrm{ij}}$ dengan mengalikan bobot kriteria dengan hasil normalisasi

$$
\begin{aligned}
& \mathrm{y}_{11}=0.3 \times 0.75=0.225 \\
& \mathrm{y}_{12}=0.26 \times 0.8=0.208
\end{aligned}
$$

dan seterusnya ..., sehingga diperoleh matriks ternormalisasi terbobot $(\mathrm{Y})$

$$
\mathrm{Y}=\left[\begin{array}{cccc}
0.225 & 0.208 & 0.135 & 0.27 \\
0.225 & 0.208 & 0.135 & 0.216 \\
0.3 & 0.26 & 0.108 & 0.216 \\
0.15 & 0.208 & 0.135 & 0.216 \\
0.15 & 0.26 & 0.135 & 0.216 \\
0.15 & 0.156 & 0.18 & 0.27
\end{array}\right]
$$

Langkah 2: Menentukan Solusi Ideal Positif $\left(\mathrm{A}^{+}\right)$, dengan persamaan (4):

$$
\begin{aligned}
& A^{+}=\left[y_{1}^{+}, y_{2}^{+}, \ldots, y_{n}^{+}\right] \\
& y_{j}^{+}=\max \left(\mathrm{y}_{\mathrm{ij}}\right) \text { pada atribut benefit dan } \min \left(\mathrm{y}_{\mathrm{ij}}\right) \\
& \text { pada atribut cost }
\end{aligned}
$$

Contoh perhitungan untuk mencari nilai $y_{j}^{+}$:

$y_{1}^{+}=\max (0.225 ; 0.255 ; 0.3 ; 0.15 ; 0.15 ; 0.15)=0.3$

$y_{2}^{+}=\max (0.208 ; 0.208 ; 0.26 ; 0.208 ; 0.26 ; 0.156)=0.26$

dan seterusnya ..., sehingga diperoleh nilai $\mathrm{A}^{+}$:

$$
\mathrm{A}^{+}=[0.3,0.26,0.108,0.216]
$$

Langkah 3: Menentukan Solusi Ideal Negatif (A-), dengan persamaan (4):

$$
A^{-}=\left[y_{1}^{-}, y_{2}^{-}, \ldots, y_{n}^{-}\right]
$$

$y_{j}^{-}=\min \left(\mathrm{y}_{\mathrm{ij}}\right)$ pada atribut benefit dan $\max \left(\mathrm{y}_{\mathrm{ij}}\right)$ pada atribut cost 
Contoh perhitungan untuk mencari nilai $y_{j}^{-}$:

$y_{1}^{-}=\min (0.225 ; 0.255 ; 0.3 ; 0.15 ; 0.15 ; 0.15)=0.15$

$y_{2}^{-}=\min (0.208 ; 0.208 ; 0.26 ; 0.208 ; 0.26 ; 0.156)=$ 0.156

dan seterusnya ..., sehingga diperoleh nilai $\mathrm{A}^{-}$:

$$
\mathrm{A}^{-}=[0.15,0.156,0.18,0.27]
$$

Langkah 4: Menentukan jarak setiap alternatif terhadap solusi ideal positif $\left(D_{i}^{+}\right)$, dengan persamaan (5):

$$
D_{i}^{+}=\sqrt{\sum_{j=1}^{n}\left(y_{i}^{+}-y_{i j}\right)^{2}}
$$

Contoh perhitungan:

$$
\begin{aligned}
D_{1}^{+} & =\sqrt{\begin{array}{l}
(0.3-0.225)^{2}+(0.26-0.208)^{2}+ \\
(0.108-0.135)^{2}+(0.216-0.27)^{2}
\end{array}} \\
& =0.10943 \\
D_{2}^{+} & =\sqrt{(0.3-0.225)^{2}+(0.26-0.208)^{2}+} \\
& =0.09517
\end{aligned}
$$

dan seterusnya ..., sehingga diperoleh $D_{i}^{+}$:

$D_{1}^{+}$RS Karsa Husada $=0.10943$

$D_{2}^{+}$RS Baptis Batu $=0.9517$

$D_{3}^{+}$RS Bhayangkara $=0$

$D_{4}^{+}$RS dr. Etty Asharto $=0.1604$

$D_{5}^{+}$RSIA HAJI $=0.15241$

$D_{6}^{+}$RS PUNTEN $=0.20351$

Langkah 5: Menentukan jarak setiap alternatif terhadap solusi ideal negatif $\left(D_{i}^{-}\right)$, dengan persamaan (6):

$$
D_{i}^{-}=\sqrt{\sum_{j=1}^{n}\left(y_{i j}-y_{i}^{-}\right)^{2}}
$$

Contoh perhitungan:

$$
\begin{aligned}
D_{1}^{-} & =\sqrt{\begin{array}{c}
(0.225-0.15)^{2}+(0.208-0.156)^{2}+ \\
(0.135-0.18)^{2}+(0.27-0.27)^{2}
\end{array}} \\
& =0.10175 \\
D_{2}^{-} & =\sqrt{\begin{array}{c}
(0.225-0.15)^{2}+(0.208-0.156)^{2}+ \\
(0.135-0.18)^{2}+(0.216-0.27)^{2}
\end{array}} \\
& =0.1152
\end{aligned}
$$

dan seterusnya ..., sehingga diperoleh $D_{i}^{-}$:

$D_{1}^{-}$RS Karsa Husada $=0.10175$

$D_{2}^{-}$RS Baptis Batu $=0.1152$
$D_{3}^{-}$RS Bhayangkara $=0.20351$

$D_{4}^{-}$RS dr. Etty Asharto $=0.08744$

$D_{5}^{-}$RSIA HAJI $=0.12533$

$D_{6}^{-}$RS PUNTEN $=0$

Langkah 6: Menentukan nilai preferensi untuk setiap alternatif dengan persamaan (7):

$$
V_{i}=\frac{D_{i}^{-}}{D_{i}^{-}+D_{i}^{+}}
$$

Dengan persamaan di atas, maka diperoleh:

$$
\begin{aligned}
& V_{1 \text { RS Karsa Husada }}=\frac{0.10175}{0.10175+0.10943}=0.48184 \\
& V_{2 \text { RS Baptis Batu }}=\frac{0.1152}{0.1152+0.09517}=0.54759 \\
& V_{3 \text { RS Bhayangkara }}=\frac{0.20351}{0.20351+0}=1
\end{aligned}
$$

$V_{4}$ RS dr. Etty Asharto $=\frac{0.08744}{0.08744+0.16104}=0.35189$

$V_{5 \text { RSIA HAJI }}=\frac{0.12553}{0.12553+0.15241}=0.45164$

$V_{6 \text { RS PUNTEN }}=\frac{0}{0+0.20351}=0$

Kemudian menentukan peringkat berdasarkan nilai preferensi dari setiap alternatif yang sudah dihitung sebelumnya. Berikut hasil peringkat setiap alternatif.

Tabel 4. Hasil nilai preferensi dan peringkat

\begin{tabular}{|l|c|c|}
\hline \multicolumn{1}{|c|}{ Alternatif } & $\begin{array}{c}\text { Nilai } \\
\text { Preferensi }\end{array}$ & Peringkat \\
\hline RS Karsa Husada & 0.48184 & $\mathbf{3}$ \\
\hline RS Baptis Batu & 0.54759 & $\mathbf{2}$ \\
\hline RS Bhayangkara & 1 & $\mathbf{1}$ \\
\hline $\begin{array}{l}\text { RS dr. Etty } \\
\text { Asharto }\end{array}$ & 0.35189 & $\mathbf{5}$ \\
\hline RSIA HAJI & 0.45164 & $\mathbf{4}$ \\
\hline RS PUNTEN & 0 & $\mathbf{6}$ \\
\hline
\end{tabular}

\section{Tampilan Halaman Web untuk Pemilihan Rumah Sakit}

\section{a) Halaman Home dan Halaman Kriteria}

Halaman ini berisi informasi mengenai kegunaan web tersebut dan menu lain yang disediakan yaitu Kriteria, Alternatif, dan Perhitungan.

Halaman kriteria memberikan informasi kriteria yang diperlukan dalam pemilihan rumah sakit dilengkapi dengan bobot dan jenis atribut (benefit atau cost). 


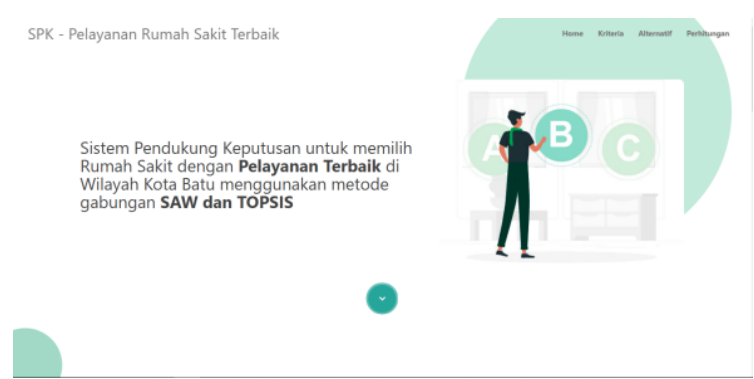

Gambar 2. Halaman home

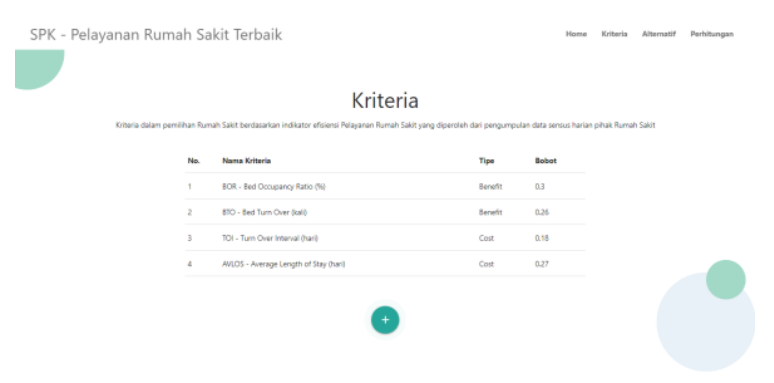

Gambar 3. Halaman kriteria

\section{b) Halaman Alternatif dan Halaman Perhitungan}

Pada halaman ini, akan ditampilkan alternatifalternatif yang akan dipilih. Pengguna bisa menambahkan, mengedit dan menghapus alternatif. Halaman ini menunjukkan hasil perhitungan yaitu nilai preferensi dan peringkat dari setiap alternatif. Hasil preferensi pada website telah sesuai dengan perhitungan manual, namun prosesnya bisa lebih cepat.

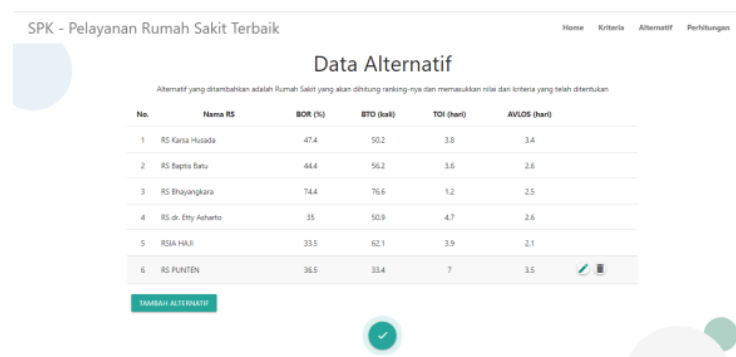

Gambar 4. Halaman alternatif

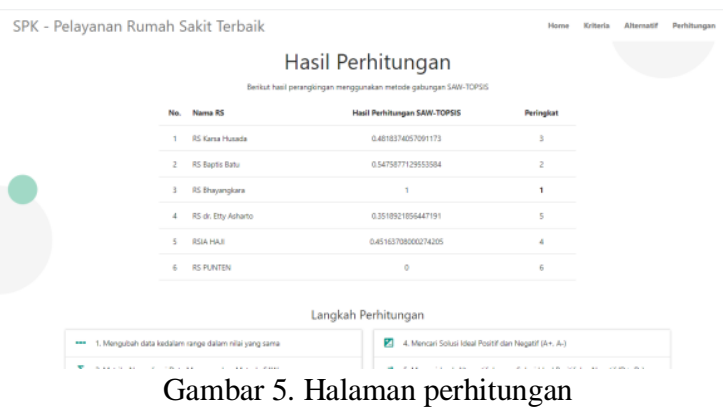

Di bagian bawah pada halaman perhitungan, terdapat penjelasan setiap langkah dalam perhitungan pengambilan keputusan menggunakan gabungan metode SAW dan metode TOPSIS sehingga user lebih paham.

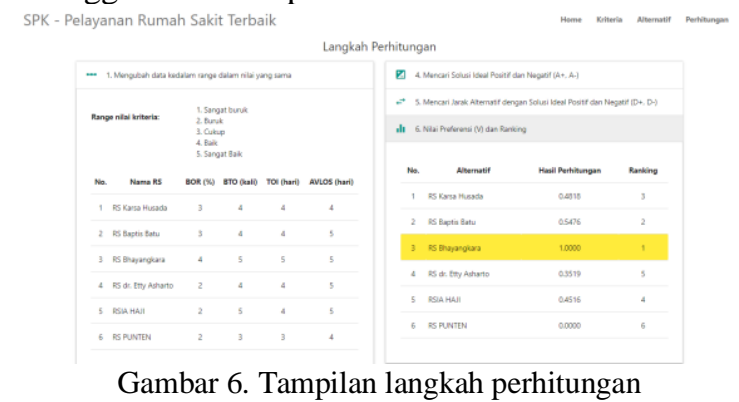

\section{Kesimpulan dan Saran}

Berdasarkan hasil penelitian dan pembahasan diatas, maka dapat disimpulkan bahwa:

1) Penggabungan antara metode SAW dan metode TOPSIS menggunakan perhitungan matematis yang lebih sederhana, cepat dan hasilnya cukup efisien untuk pengambilan keputusan dengan alternatif yang tepat, seperti hasil penelitian - penelitian sebelumnya.

2) Hasil perhitungan manual dengan perhitungan pada website sesuai. Namun lebih cepat dan efisien jika menggunakan sistem.

3) Nilai bobot (w) dan jumlah kriteria sangat berpengaruh terhadap hasil perhitungan.

4) Sistem pendukung keputusan untuk memilih rumah sakit dengan pelayanan rawat inap terbaik diharapkan dapat membantu masyarakat dalam memilih rumah sakit.

Adapun saran untuk penelitian berikutnya adalah membuatkan program yang lebih efisien dengan penambahan kriteria ataupun metode perhitungan untuk meningkatkan ketepatan hasil pengambilan keputusan.

\section{Daftar Pustaka:}

Büyüközkan, Gülçin. Güler, Merve. (2019). Smart Watch Evaluation with Integrated Hesitant Fuzzy Linguistic SAW-ARAS Technique. MEASUR Journal 107353

Catho, Gaud. Centemero, Nicolò Saverio. Catho, Heloïse. Ranzani, Alice. Balmelli, Carlo. Landelle, Caroline. Zanichelli, Veronica. Huttner, Benedikt David. (2020). Factors determining the adherence to antimicrobial guidelines and the adoption of computerised decision support systems by physicians: A qualitative study in three European hospitals. International Journal of Medical Informatics 1 41.

Depkes RI, (2005): Petunjuk Pengisian, Pengolahan, dan Penyajian Data Rumah Sakit, Jakarta

Fristy R., Paska \& Insan (2017): Sistem Pendukung Keputusan Menggunakan Metode Topsis Dalam 
Memilih Kepala Departemen Pada Kantor Balai Wilayah Sungai Sumatera Ii Medan, Journal Of Informatic Pelita Nusantara,vol. 2, pp. 8

Gregorius, Ernawati \& Irya, (2013):Analisis Penggabungan Metode SAW dan Metode TOPSIS Untuk Mendukung Keputusan Seleksi Penerimaan Dosen, Seminar Nasional Informatika 2013 (semnasIF) UPN "Veteran" Yogyakarta.

Hatta, Gemala R. (2013): Pedoman Manajemen Informasi Kesehatan di Sarana Pelayanan Kesehatan, Jakarta: UI Press.

Ismail, Omar S. (2015). The Use of a Mobile-Based DecisionSupport System in Agriculture: AnInterpretive Case Study in Southwest and Central Bangladesh. Florida State University Libraries

Komisi Akreditasi Rumah Sakit, Daftar Rumah Sakit Terakreditasi Kota Batu, Tersedia: http://akreditasi.kars.or.id/application/report/rep ort_accredited.php.

Konstantinos, Ioannou. Georgios, Tsantopoulos. Garyfalos, Arabatzis. (2019). A Decision Support System methodology for selecting wind farm installation locations using AHP and TOPSIS: Case study in Eastern Macedonia and Thrace region, Greece. Energy Policy Journal Volume 132, September 2019, Pages 232-246

Munthe, Hotmaria Ginting, (2013): Sistem Pendukung Keputusan Penentuan Prioritas Usulan Sertifikasi Guru Dengan metode Simple Additive Weighting, Medan: Pelita Informatika Budi Darma vol. IV No. 2:52-58.

Ogunti, Erastus O. Akingbade, Francis K. Segun, Adebayo. Oladimeji, Oloyede. (2018). Decision Support System Using Mobile Applications in the Provision of Day to Day Information about Farm Status to Improve Crop Yield. Periodicals of Engineering and Natural Sciences. Vol.6, No.2, November 2018, pp. 89-99

Ortiz-Barrios, Miguel. Gul, Muhammet. LopezMeza, Pedro. Yucesan, Melih. (2020). Evaluation of hospital disaster preparedness by a multi-criteria decision making approach: The case of Turkish hospitals. International Journal of Disaster RiskReduction 49.

Palmu, R., Partonen, T., Suominen, K., Saarni, S. I., Vuola, J., \& Isometsä, E. (2015). Health-related quality of life 6 months after burns among hospitalized patients: Predictive importance of mental disorders and burn severity. Burns Journal Elsevier.

Paul, Mathew. Bussemaker, Madeleine J. (2020). A web-based geographic interface system to support decision making for municipal solid waste management in England. Journal of Cleaner Production 263121461

Permana, S. D. H, (2015): Sistem Penunjang Keputusan Pemilihan Sekolah Menengah Kejuruan Teknik Komputer Dan Jaringan Yang
Terfavorit Dengan Menggunakan Multi-Criteria Decision Making, Jurnal Teknologi dan Ilmu Komputer

Portal Satu Data Indonesia, Data Indikator Kinerja Pelayanan di Rumah Sakit Kota Batu Tahun 2018, Tersedia: https://data.go.id/dataset/dataindikator-kinerja-pelayanan-di-rumah-sakitkota-batu-tahun-2018

Reza, Farah, (2020): Tak Dapat Ranjang Beroda, Nenek Meninggal di Parkiran Rumah Sakit, Tersedia: https://www.suara.com/news/2020/03/19/0715 00/tak-dapat-ranjang-beroda-nenek-meninggaldi-parkiran-rumah-sakit.

Siddiqui, Atiq W. Raza, Syed Arshad. Tariq, Zeeshan Muhammad. (2018). A Web-based Group Decision Support System for Academic Term Preparation. Decision Support System Journal.

Sudra, R. I., (2010): Statistik Rumah Sakit dari Sensus Pasien dan Grafik Barber Johnson Hingga Statistic Kematian dan Otopsi, Yogyakarta: Graha Ilmu.

Yousufuddin, M., Young, N., Shultz, J., Doyle, T., Fuerstenberg, K. M., Jensen, K., Murad, M. H. (2018). Predictors of Recurrent Hospitalizations and the Importance of These Hospitalizations for Subsequent Mortality After Incident Transient Ischemic Attack. Journal of Stroke and Cerebrovascular Diseases. 
Volume 6, Edisi 4, Agustus 2020

$62 \mid \mathrm{H}$ a $\mathrm{l}$ a $\mathrm{m}$ a $\mathrm{n}$ 